\title{
The Older Adults Experience Caring for Grandchildren with Special Needs
}

\author{
Sylvia Dwi Wahyuni, Retno Indarwati, and Aditya Budi Nugroho
}

Faculty of Nursing, Universitas Airlangga, East Java, Indonesia

\begin{abstract}
Introduction: Nowadays, grandparents are still involved in the care of grandchildren. The previous research showed that the grandparent involvement in the care of grandchildren has a bad and good impact for older adults. This study aims to gain a deep understanding of the experience of older adults while caring for their grandchildren with special needs.
\end{abstract}

Methods: Researchers use a phenomenological approach to explore the experience based on awareness that occurs in some individuals. The participants involved in this study were six older adults. Data were collected by in-depth interview and analyzed by Colaizzi's method.

Results: All participants have grandchildren who attended school for special needs children in Surabaya city. This study showed all participants responded positively and related involvement in taking care of grandchildren. In addition, the decision to being a part of caring for the grandchildren came from themselves and the discussions with both parents. Most of the activities with grandchildren were spending time together. However, all participants complained of being tired and this condition can be solved by seeing grandchildren's happiness. They believed that grandchildren care is better with grandmothers or grandfathers than with servants.

Conclusion: It can be concluded that the experiences of the older adult taking care of grandchildren are very varied and positive for the older adults. Further researchers are advised to continue to explore more detail about the psychological influence of grandparents taking care of their grandchildren with special needs.

\section{ARTICLE HISTORY}

Received: June 13, 2021

Accepted: October 11, 2021

\section{KEYWORDS}

older adults; experience; caring; grandchildren with special needs

\section{CONTACT}

Sylvia Dwi Wahyuni

$\bigotimes$ sylvia.dwiwahyuni@fkp.unair.ac.id

$\equiv$ Faculty of Nursing, Universitas

Airlangga, East Java, Indonesia

Cite this as: Wahyuni, S. D., Indarwati, R., \& Nugroho, A. B. (2021). The Older Adults Experience Caring for Grandchildren with Special Needs. Jurnal Ners, 16(2). 128-134. doi:http://dx.doi.org/10.20473/jn.v16i2.27479

\section{INTRODUCTION}

In general, there are challenges for families raising children with special needs (Franklin, 2020). Children who have physical, mental, and social behavioral characteristics (such as: communication disorder, social interaction difficulties, emotional disturbances and others) need special strategies and approaches in treatment (Tigere \& Makhubele, 2019). On the one hand, there is a change in the pattern of the role of mothers as career women and housewives so that other family members in the family (extended family) such as grandmothers will become substitute figures for parents while caring for their grandchildren (Wahyuni \& Abidin, 2015). Preliminary studies conducted by researchers at several Sekolah Luar Biasa (Extraordinary Schools, a school for children with special needs) in Surabaya city showed that children with special needs are more cared for by their grandparents than their parents. Based on the initial data survey through interviews with the principal, information was obtained that the number of older adults with grandchildren was approximately 20 people. Various experiences make parents more comfortable if the care of grandchildren is carried out by the older adults than others, such as a babysitter. However, the description of the experience of the older adults in the care of their grandchildren is still not clearly illustrated. The purpose of this study was 
to explore the older adults who are involved in the care of grandchildren with special needs.

On the other hand, the care of grandchildren has positive and negative impacts to the older adults (Fauziningtyas et al., 2018). The care of grandchildren for older adults has a positive impact on physical, psychological, social, and environmental aspects (Putu et al., 2020). Based on the other research, grandmothers and grandfathers who are involved in caring their grandchildren reported higher rate of life satisfaction and quality of life than non-grandparents. The result also show that grandmothers reported fewer depressive symptoms than women without grandchildren (Tanskanen et al., 2019).In addition, the older adults who were interviewed accepted gracefully if they were given responsibility for caring for their grandchildren. However, there are also negative effects such as fatigue and family conflict (Fauziah, 2020). The major factor that affected grandparents' health self-management who involved in taking care of grandchildren was caregiving burden (Jing \& Guo, 2019).

Meanwhile, many older adults in Indonesia live with their families. The older adults who live with their families in three generations are as much as 40.64\% (Statistik, 2019). Moreover, Indonesia is among the top five countries with $8.9 \%$ older adults in 2013 and will increase to $21.4 \%$ in 2050 (BPS \& Jawa Timur, 2012). The number of adults aged $>60$ years in East Java Province is 3.6 million people (BPS \& Jawa Timur, 2012). The number of older adults aged $>60$ years in Surabaya in 2019 is 256,007 people (Surabaya, 2019). In addition, the Central Statistics Agency (BPS) in 2017 stated that the number of children with special needs in Indonesia was 1.6 million people. However, there is no definite data regarding the number of older adults who care for grandchildren (Fauziningtyas et al., 2018).

Based on the background above, the experience of the older adults in the care of grandchildren with special needs to be explored. The description of this experience can be explored by qualitative research through in-depth interviews. Therefore, the researchers are interested in seeing a picture of that specific experience.

\section{MATERIALS AND METHODS}

This research is a qualitative method with a phenomenological approach. The population were the older adults with grandchildren who attend an extraordinary school in Surabaya. Sampling method used purposive sampling with the following criteria: 1) older adult aged 60-74 years, 2) take care of grandchildren for 1-12 hours per day, 3) live with grandchildren, and 4) grandchildren who attend extraordinary schools. The number of participants in the study was six older people.

Data collection tools consisted of interview guidelines, voice recorder, and field notes. The interview used open questions and consisted of fourteen questions that aim to explore the experience of grandparents in caring for grandchildren with special needs. The question framework was based on the theory of family centered nursing.

Researchers conducted interviews with participants in a facing position with a fairly close distance (approximately 50-100 cm), with the consideration that the voice recorder could record the conversation clearly. The voice recorder was placed in the open with a distance of approximately 30-50 cm from the participants.

The interview process in the study lasted for 60 90 minutes for each participant, ending when the required information had been obtained according to the research objectives through saturation. In addition, field notes were used to document the atmosphere, facial expressions, behavior and nonverbal responses of participants during the interview process. After all the interviews were completed, the researcher then made a contract again with the participants for the next meeting, namely for data validation.

Furthermore, the researcher ignores all personal assumptions related to the phenomenon under study when digging research data, puts aside his personal knowledge and understanding, and tries fully to position himself as a participant and see things from the participant's perspective. This concept is called epoche or bracketing.

The data were analyzed by the Colaizzi method. The data analysis was through nine stages as follows: describe the phenomenon under study, collecting descriptions of phenomena through participant opinions; read the entire description of the participants about the phenomenon being studied, separating significant statements by giving a code to participant statements that have significant meaning listed verbatim; formulate the meaning of each significant statement; categorize each unit of meaning into one theme/cluster of meaning; integrate each theme into a complete description, validating the results of the analysis to participants, and improving the results of the analysis with the data obtained during the validation process.

This study has passed the ethical test by the Ethics Committee of the Faculty of Nursing, Universitas Airlangga.

\section{RESULTS}

Participants in this study were six older adults consisting of one male and five female older adults. This study resulted in nine themes that were elaborated according to the research objectives to obtain a deep understanding of the experiences of the older adults and grandchildren with children with special needs. The data on the characteristics of grandparents and grandchildren are presented in the table below.

\section{Theme 1: Caring Engagement}

Participants in this study expressed a meaningful response based on their involvement with the mother 
Table 1. Grandparent Characteristics

\begin{tabular}{|c|c|c|c|c|c|c|}
\hline Participant & Gender & Education level & Profession & Religion & Marital Status & Age (year) \\
\hline 1 & Female & Junior high school & Housewife & Islam & Married & 67 \\
\hline 2 & Male & Senior high school & Retired & Islam & Married & 72 \\
\hline 3 & Female & Junior high school & Housewife & Islam & Married & 66 \\
\hline 4 & Female & Diploma III & Housewife & Islam & Married & 65 \\
\hline 5 & Female & Diploma III & Retired & Islam & Widow & 68 \\
\hline 6 & Female & Junior high school & Housewife & Islam & Widow & 72 \\
\hline
\end{tabular}

Table 2. Grandchildren Characteristics

\begin{tabular}{cccc}
\hline Participant & Gender & Age (year) & Special condition \\
\hline 1 & Male & 12 & Down Syndrome \\
2 & Male & 16 & Down Syndrome \\
3 & Female & 10 & Down Syndrome \\
4 & Female & 10 & Down Syndrome \\
5 & Male & 11 & Down Syndrome \\
6 & Female & 14 & Down Syndrome \\
\hline
\end{tabular}

and grandchildren. All participants responded positively, namely accepting anything related to involvement with the mother of the grandchildren and one sub-theme was obtained, namely that the older adults were involved in caring for their grandchildren for one full day. Statements about involvement in the mother and grandchildren were expressed by the following participants:

\section{Custodian}

"Currently, this child's parents are already working, so $100 \%$ of the care is with me and my wife. Actually they have a house but it is not inhabited because we chose to raise this child here." (P2)

"As a grandmother, I take care of all day, starting to drop off school in the morning, take care when at home and outside the house because this child with special needs requires full attention. Eating, drinking, and resting time should also be a priority." (P4)

\section{Theme 2: The feeling of caring for grandchildren with special needs}

\section{Gratitude}

"Yes, he feels grateful to be able to teach him all the time, to keep talking, if not invited to talk, his child will continue to be silent like this. So ... oh no ... just be grateful if I just give thanks for the gift of Allah SWT. Yes, if asked to sing, taught to recite the Koran, that's how it used to be if now I rarely want to talk about it like that...." (P1)

\section{Happy}

"Yes, I am happy, bro, I have never had grandchildren, that only grandchildren, but yes, God gave it, yes, we accept it as it is, bro. Maybe there are people who are ashamed, but I'm not ashamed, bro, entrusted it like that, inshaAllah, bro, because it was a deposit from God, bro, my mandate, bro, I will feel guilty. Actually, I'm sorry to see a child like that, for example learning, the obstacle is lazy, bro, if you can actually learn, bro, it's just that there is less interest in learning, bro, so it's hard there, so you have to be patient...." (P6)

\section{Sad}

"As a human, sometimes there is sadness, sometimes there is anger. It's sad if someone wants their grandchildren, since I was little I took care of them so there were signs 'this body is not feeling well or something,' that's sad...." (P2)

\section{Annoyed}

"Sometimes I get annoyed because I can't say if I want to pee so I still use a pamper, so I don't to the point of littering the house. So he can't be independent yet...." (P6)

\section{Angry}

"Sometimes I get angry because he doesn't obey, but I really love him. Angry at my grandchildren can't really be angry. He's just a matter of taking a shower is hard. He didn't even want to enter the bathroom, so we had to seduce him with a gold toy so that his grandson would go to the bathroom and take a shower...." (P3)

\section{Attention}

"Yes, it's normal, it's normal, children with special needs need affection, so if their parents can't take care of it, I take care of it...." (P5)

\section{Fatigue}

"That's the complaint, my legs get tired sometimes because I have gout...." (P1)

\section{Theme 3: Parenting Decisions}

\section{Self-decision}

"They (parents and grandchildren) all work so I take a stand to take care of him. If a helper is handed over, it is not certain that it will be done. There is also no coercion in the care of grandchildren...." (P5)

\section{Joint decision}

"His parents work, yes, we want to happily accept them together with his siblings as well, we are very supportive, so this is a mutual agreement, while people wanted to take it in the past, but we are 
afraid because we are not in the same heart as we are afraid that something will happen to my grandchild. I used to have a student like this but he was not active, still like that, he continued to drink, he was given medicine, he continued to sleep and was left behind, how about that? Well, I'm very scared, and I will think if there is something wrong with our grandchildren, so now we are just worried...." (P3)

\section{Theme 4: Activities during parenting}

\section{Learning}

"Sometimes he studies, if he's in the mood we guide him, but if he is forced, he doesn't want to...." (P3)

\section{Worship}

"I thank Allah SWT for the first time, he often saw me praying five times at that time, now he is the one who tells me the time for prayer and keeps saying he wants to go to the mosque or mosque, so he wants to ask to move to the prayer room, evening prayer at the prayer room for evening prayer' The mosque is close to me, so I follow the problem according to my wishes...." (P2)

\section{Taking a walk}

"Where have you been if you want to walk like that, if I get it, go for a walk with his brother, younger brother, his father, his mother. Yes, I sometimes walk to TP, yes, but sometimes if I want to go to Malang, like yesterday, I didn't go along, I was tired so I couldn't join...." (P5)

\section{Playing}

"Yes, I usually bathe, yes I am invited to play. Come on, don't worry, yes that's usual, I want to ask for my pan to give me a bribe..." (P4)

\section{Watching TV}

"Grandma watching TV together, sometimes you listen to radio, listen to me..." (P6)

\section{Doing homework}

"In the morning, cook, cook, there are employees, right? Yes, I did cook. This is when it's still early morning with the mother, so I'll cook later if I want to go to a new school with me, right, there is a mother in the morning too. Brother, when night sleeps with his mother, this is the little one who sleeps with me, this is the second grandchild of my child..." (P1)

\section{Selling snacks in front of the house}

"I help my son sell snacks in front of the house, I also help wholesale the ingredients when they run out. It's good to be able to fill time and increase income." (P2)

\section{Community activities}

"Yes, at home, there are RW activities, mas, if there is a recitation and at home, the mother will take care of the mother. If the recitation in the mosque is Wednesday and Friday then the routine recitation is every Wednesday, sometimes Wednesday, sometimes it's Wednesday, sometimes someone asks for Saturday or Sunday, but if there are no parents, I don't dare to die, if the parents haven't come home, I don't have the courage. Died mas still a little pity...." (P4)

\section{Theme 5: Fulfillment of daily needs}

\section{Meeting the needs of children from parents}

“Grandchildren's daily needs are met by their parents, we (grandfathers) only buy snacks when our grandchildren ask for it." (P2)

"All the needs of grandchildren are met by his father because his mother does not work." (P4)

\section{Compliance with the grandchildren needs by grandparent}

"I also help meet the needs of my grandchildren because I have a pension every month." (P4)

"I fulfill all the needs of my grandchildren because their parents need a lot of other expenses including therapy." (P6)

\section{Theme 6: Addressing complaints}

\section{Break}

"Yes, sleep, rest and take medicine so that we don't get tired the next day we can do what we do again, so take care of the man...." (P3)

\section{Pray}

"I always pray for my grandson. I recited a verse about illness so that my grandson's illness would be removed. In addition, the doctor also said that before taking medication, read a prayer first. I believe God will help us if we pray." (P2)

\section{Get treatment}

"Yes, you anticipate if the medicine is routine every day, you have to drink it, sometimes you get hit with food, which may be too salty, so sometimes you are alert, sometimes you fight, bro. Cholesterol is indeed from a lot of fried foods, but if you boil tempeh, it's not delicious if it's not fried. The doctor's advice is not too strict on a diet, you just have to reduce it, but sometimes chronic disease conditions change to become uncomfortable, right, the mind can also catch a cold too. Yes, if he sleeps sometimes I can definitely rest if I don't sleep, I can't...." (P5)

\section{Theme 7: Attitudes and perceptions}

\section{Informational support}

"Yes, you already know that the neighbors often ask 'Where are you being treated?' Yes, I said therapy. So you usually just ask" 'Mom, mom?' Yes, you can do it yourself, if you don't bring up your own children, you can run away, but you can do it, Mom. 


\section{Receive}

"Ohhh nothing, if in my neighborhood where there is a grandmother it is commonplace to take care of the grandchild because it seems like there is a grandmother, so if you want to join her grandmother, it doesn't matter because there is a tradition here...." (P4)

\section{Disregard}

"It's not important to the neighbors, although there are assumptions that there are those who tend to talk like that, but my grandson, how come I don't receive payment, not forced to, if he thinks it's good, please if not yes please...." (P5)

\section{Ordinary}

"Just normal, you don't say the one who takes care of me is only the parents saying thank you. Yes, if I asked for this, it was bought because it was spoiled education. If I did that, I taught Dewe. I should just have to rest because it is still needed so I have to help. I myself am a maid in Mongol, so don't have the heart for people to be the same, how come sometimes there are people who clam up, there is something like that, because they are still able to move unless there is no strength...." (P5)

\section{Gossip}

"Yes, it is common for villagers to talk about their son-in-law, but I don't care about it ..." (P6)

\section{Theme 8: Family Interaction}

\section{Harmonious}

"There is no problem, our relationship is all good...." (P4)

\section{Lack of communication}

"Yes, the interaction with my son number 5 is not good, like a disobedient child because he never calls. My son-in-law often wanders around rarely at home...." (P6)

\section{Theme 9: Hope}

\section{Independent}

"Yes, he can continue to be independent on his own. If God gives him health, independence can be useful for the mother and father, just like that. Independent in any way and must be supervised by parents. We support you together, you take care of each other. Grandchildren and children are stickier to grandchildren...." (P3)

\section{Healthy}

"Yes, there is a limit, it's impossible for him to be faced with becoming an engineer. no need to be grandiose the important thing is healthy...." (P5)

\section{DISCUSSION}

The involvement of the older adults caring for grandchildren in this study is the role of the grandparents in meeting the educational and physical needs of the grandchildren. The role of the older adults is needed in the growth and development of grandchildren. Raising grandchildren is a shared responsibility of grandparents and parents. This is in line with the previous research (Fauziningtyas et al., 2018). Moreover, about $80 \%$ of grandparents say they are happy with their grandchildren (Santrock, 2002). The fundamental value in the family structure in Asia is to place parents as parties to be held and respected (Pujiatni \& Kirana, 2013). The family maintains relationships between generations, where the early generations will always leave an influence on the next generation (Santrock, 2002). In addition, participants had feelings of joy during their time with their grandchildren and some older adults experienced or had complaints when caring for their grandchildren, but these complaints disappeared when the older adults saw their grandchildren happy. This is in line with research conducted by Rista et al. which states that "Grandparenting" in Java provides positive experiences and feelings of happiness for grandparents (Fauziningtyas et al., 2018). The experience gained by the older adults can make them the right figure to provide a benchmark for family values that should be applied (Pujiatni \& Kirana, 2013). Moreover, the existence of a family can achieve individual needs such as support, love, and emotions like happiness (Wahyuni \& Abidin, 2015).

Furthermore, participants said that they tend to make decisions for themselves because the older adults think that their grandchildren are everything and are the successor of the family. This is in line with previous research (Wahyuni \& Abidin, 2015) which states that the experience gained by the older adults makes them a figure appropriate to provide a benchmark for family values that should be applied. Decisions that are taken collectively are due to the busy careers of the parents of the child. Furthermore, a family can be decisive in making decisions on other family members (Kertamuda, 2009). Likewise, grandchildren will learn ways to achieve social roles for themselves.

Additionally, participants often spent their time doing activities with their grandchildren. The older adults also do other activities when they do not care for their grandchildren, such as participating in community activities and doing household chores. This condition is similar to Papalia and Olds (2008) who found that the grandparents' activities are often having dinner together, watching television, shopping, and practicing or playing sports with their grandchildren. According to Duvall, the developmental task at old age is to adjust the stage of retirement by changing ways of life; the older adults accept the death of a partner, friends and prepare for death, the older adults maintain the intimacy of their partner and care for each other, and carry out past life 
reviews (Setiadi, 2008). Santrock (2002) said that successful aging indicates the success of the older adults in facing the changes that occur in their life. This success is characterized by the ability to perform daily activities such as homework (Peterson, 2017).

Almost all of the fulfillment of the needs of the grandchildren came from both parents and grandparent. However, some grandparents meet almost all the needs of grandchildren because their mothers are not working and the older adults have pension funds. According to Papalia and Olds (2008), more than half of grandparents spend money on the needs of their grandchildren. Grandparents take care of their grandchildren while their parents work and prepare school supplies for their grandchildren, wait for their grandchildren's school, until they come home from school and at home. The fulfillment of formal and informal support for the older adults in raising grandchildren is in the form of fulfilling financial needs in the form of money (Choi, Sprang, \& Eslinger, 2016).

Participants think that there are no damning complaints, everything can be resolved. It turns out that every time a complaint comes, the older adults feel paid off when they see their cute and healthy grandchild. Psychologically, physical fatigue can be relieved by praying in overcoming the disease. This is in line with research which states that grandparents only raise grandchildren when their children work; when parents have returned from work, the grandchildren are handed back to their parents. In addition, they said that they did not only talk to their grandchildren, they could be involved in other activities. For rest hours, the older adults feel very adequate because, when their grandchildren take a nap, the older adults also take a nap so they don't feel disturbed for resting (Suyanta \& Ekowarni, 2012).

The attitudes and perceptions of the participants obtained different results, that the responses from neighbors about their grandchildren were different, some were normal, some supported helping remind, and some did not care. Older adults also sometimes hear words that are not wearing from people around them but the older adults choose to ignore it and stay focused on taking care of their grandchild. Parent figures in the extended family have a meaning in regard to parenting the children (Yulion, 2013). Parents trust more when their children are taken care of by grandparents than when they have to leave with someone else. This is in accordance with research which states that various experiences make a child believe that the care of grandchildren is carried out by the older adults rather than others outside the family, such as babysitters (Pujiatni \& Kirana, 2013). Each family member must support each other because of an absolute obligation; momong and grandchildren are natural (Bulanda \& Jendrek, 2014).

Good relationships and support from family can help minimize discontinuity in the older adults (Papalia \& Olds, 2008). A warm relationship with children is the highest support for the older adults. Therefore, a good relationship between children, son- in-law, grandchildren and family is very good for the older adults psychologically.

Older adults are happy in continuing to care for their grandchildren because the older adults want their grandchildren to learn ways to achieve social roles for themselves. There is also a developmental task for the older adults, which is called a life review, and allows the older adults to see the past that is in their grandchildren so that the older adults are very happy if they continue to care for their grandchild because they see their old identity in their grandchild (Wahyuni \& Abidin, 2015).

\section{CONCLUSION}

Overall, this study shows that all participants felt positive experiences during grandparenting. Participants expressed the same response regarding the meaning of a grandchild. They believed that grandchildren are everything, beyond their own children, a diamond, a gift and a pride. In addition, they had feelings of joy at the birth of grandchildren and the decisions of grandparenting were from themselves. Most of the activities that are often done with grandchildren are playing. The other activities were participating in community activities, taking care of the household, watching TV, and selling snacks in front of their house. On the other hand, the feeling of tiredness and negative experiences will disappear when they see their grandchildren happy and cheerful. All participants think that the care of grandchildren is better with grandparents than with helpers.

\section{REFERENCES}

BPS \& Jawa Timur. (2012). Profil Penduduk Lanjut Usia Provinsi Jawa Timur.

Bulanda, J. R., \& Jendrek, M. P. (2014). Grandparenting Roles and Volunteer Activity. The Journals of Gerontology, Series B 71(1) January 2016 1-11. https://doi.org/10.1093/geronb/gbu033

Choi, M., Sprang, G., \& Eslinger, J. G. (2016). Grandparents Raising Grandchildren: A Synthetic Review and Theoretical Model for Interventions. Family \& community health, 39(2), 120-128. https://doi.org/10.1097/FCH.00000000000000 97

Fauziah, N. (2020). The Role of Grandmother ' s Grandparenting on Family Harmony: a Phenomenological Analysis. Journal of Educational, Health, and Community Psychology, 9(4), 574-590.

Fauziningtyas, R., Indarwati, R., Alfriani, D., Haryanto, J., \& Ulfiana, E. (2018). The experiences of grandparents raising grandchildren in Indonesia Working with Older People, 23(1), 17-26 https://doi.org/10.1108/WWOP-10-2018-0019

Franklin, P. A. (2020). Impact of disability on the family structure. Social Security Bulletin, 17(6), 14711-14729.

Jing, X. W., \& Guo, C. C. (2019). The implications of childcare on grandparents ' health self- 
management in a Chinese elderly population. Int J Health Plann Mgmt, September, 1-10. https://doi.org/10.1002/hpm.2904

Kertamuda. (2009). Konseling Pernikahan dalam Keluarga.

Papalia Diane. E, Old Sally Wendkos, F. R. D. (2008). Human Development (Psikologi Perkembangan) (9th ed.). Kencana.

Peterson, T. L. (2017). Social Work in Public Health Changes in Health Perceptions among Older Grandparents Raising Adolescent Grandchildren Adolescent Grandchildren. Social Work in Public Health, 32(6), 394-406. https://doi.org/10.1080/19371918.2017.13273 89

Pujiatni, K., \& Kirana, A. (2013). Penjaga Nilai-Nilai Dalam Keluarga: Peran Kakek Dan Nenek Dalam Pengasuhan Cucu. 302-309.

Putu, N., Narayani, R., Menik, K., \& Krisnawati, S. (2020). Hubungan intensitas pengasuhan сиси dengan kualitas hidup lansia. 8(April), 25-32.

Santrock, J. W. (2002). Life-Span Development, Perkembangan Masa Hidup (5th ed.) (5th ed.). Erlangga.

Suyanta, S., \& Ekowarni, E. (2012). Pengalaman Emosi dan Mekanisme Koping Lansia yang Mengalami Penyakit Kronis. Jurnal Psikologi, 39(2), 208-221.
Setiadi. (2008). Konsep Dan Proses Keperawatan Keluarga. Graha Ilmu.

Statistik, B. P. (2019). Katalog: 4104001. Badan Pusat Statistik.

Surabaya, B. (2019). Penduduk Lanjut Usia Kota Surabaya.

Tanskanen, A. O., Danielsbacka, M., Coall, D. A., \& Jokela, M. (2019). Transition to Grandparenthood and Subjective Well-Being in Older Europeans : A Within-Person Investigation Using Longitudinal Data. Evolutionary Psychology, September, 1-12. https://doi.org/10.1177/1474704919875948

Tigere, B., \& Makhubele, J. C. (2019). The experiences of parents of children living with disabilities at Lehlaba protective workshop in Sekhukhune district of Limpopo province. African Journal of Disability, $8, \quad 1-9$. https://doi.org/10.4102/ajod.v8i0.528

Wahyuni, Y. T., \& Abidin, Z. (2015). Pengalaman Hidup Lansia Yang Mengasuh Cucu: Studi Kualitatif Fenomenologis dengan Interpretative Phenomenological Analysis. Jurnal Empati, 4(4), 8-14.

Yulion, M. M. (2013). Memahami Pengalaman Komunikasi Pengasuhan Anak Dalam Extended Family. 